\title{
Utilization of roughages and concentrates relative to that of milk replacer increases strongly with age in veal calves
}

\author{
H. Berends, ${ }^{\star 1,2}$ J. J. G. C. van den Borne, ${ }^{*}$ H. Mollenhorst, $†$ C. G. van Reenen,§ E. A. M. Bokkers, $†$ \\ and W. J. J. Gerrits* \\ *Animal Nutrition Group, Wageningen University, PO Box 338, 6700 AH Wageningen, the Netherlands \\ †Animal Production Systems Group, Wageningen University, PO Box 338, 6700 AH Wageningen, the Netherlands \\ łBusiness Economics Group, Wageningen University, PO Box 8130, $6700 \mathrm{EW}$, the Netherlands \\ §Livestock Research, Animal Sciences Group, Wageningen University and Research Centre, PO Box 65, 8200 AB Lelystad, the Netherlands
}

\section{ABSTRACT}

We aimed to investigate the feeding values of milk replacer (MR), roughage, and concentrates for veal calves in a paired-gain setting, thus avoiding any prior assumptions in feeding values and major differences in nutrient intakes. One hundred sixty male HolsteinFriesian calves at 2 wk of age and $45 \pm 0.2 \mathrm{~kg}$ of body weight $(\mathrm{BW})$ were included in the experiment. Calves were allocated to pens ( 5 calves per pen) and pens were randomly assigned to 1 of 4 solid feed (SF) levels: SF1, SF2, SF3, or SF4, respectively, and to 1 of 2 roughageto-concentrate (R:C) ratios: 20:80 or 50:50. An adaptation period from wk 1 to 10 preceded the experimental period (wk 11 to 27). Total dry matter (DM) intake from SF was targeted to reach 20,100, 180, and $260 \mathrm{~kg}$ of DM for SF1 to SF4, respectively, during the 16-wk experimental period, and increased with preplanned, equal weekly increments. Roughage was composed of $50 \%$ corn silage and $50 \%$ chopped wheat straw based on DM. The quantity of MR provided was adjusted every 2 wk based on BW to achieve similar targeted rates of carcass gain across treatments. The reduction in MR provided (in $\mathrm{kg}$ of $\mathrm{DM}$ ) to realize equal rates of carcass gain with inclusion of SF (in $\mathrm{kg}$ of DM) differed between the $\mathrm{R}: \mathrm{C}$ ratio of $50: 50(0.41 \mathrm{~kg}$ of $\mathrm{MR} / \mathrm{kg}$ of $\mathrm{SF})$ and the R:C ratio of $20: 80(0.52 \mathrm{~kg}$ of $\mathrm{MR} / \mathrm{kg}$ of $\mathrm{SF})$. As carcass gain unintentionally increased with SF intake, the paired-gain objective was not fully achieved. When adjusted for realized rates of carcass gain, calves fed an R:C ratio of 20:80 still required 10\% less MR than calves fed an R:C ratio of 50:50 for equal rates of carcass gain, indicating that the utilization of SF for gain increased with concentrate inclusion. Averaged for the 16-wk experimental period, the feeding value of

Received March 1, 2014

Accepted July 5, 2014.

${ }^{1}$ Corresponding author: Harma.Berends@nutreco.com

${ }^{2}$ Current address: Nutreco Ruminants Research Centre, Veerstraat 38, 5831 JN Boxmeer, the Netherlands.
$\mathrm{MR}$ relative to that of concentrates and roughages was close to that predicted based on their respective digestible energy contents. Nevertheless, the feeding value of SF relative to that of MR increased substantially with age. Therefore, additivity in feeding values of these ration components cannot be assumed. The results of the current study may contribute to the development of new concepts for formulation of veal calf diets with substantial amounts of SF.

Key words: veal calf, growth performance, nutrient utilization, forage

\section{INTRODUCTION}

Provision of a minimum daily amount (50 to $250 \mathrm{~g}$ ) of fibrous feed for veal calves is compulsory according to guidelines of the European Union. Solid feed (SF) provision reduces nonnutritive oral behaviors (Kooijman et al., 1991; Veissier et al., 1998; Webb et al., 2012), thereby contributing to improved calf welfare. In addition, the increasing cost of milk replacer (MR) ingredients provides an economic incentive to replace MR with SF.

When combining SF and MR, interactions occurring at the level of digestion or postabsorption may influence nutrient utilization and growth performance in veal calves. Milk-fed calves provided with concentrate feed as the only SF source had signs of parakeratosis and so-called plaque formation (i.e., patches of focal mucosa inflammation with coalescing and adhering papillae covered by SF particles, hair, and cell debris), which may inhibit rumen development and nutrient uptake (Suárez et al., 2006, 2007). Early rumen development is thought to increase utilization of SF in veal calves, especially toward the end of the fattening period (Berends et al., 2012b). However, the provision of SF to veal calves may increase the prevalence of abomasal lesions (Welchman and Baust, 1987; Mattiello et al., 2002; Brscic et al., 2011) and concentrate provision has been associated with ruminal drinking; that is, leakage 
of MR into the rumen (Berends et al., 2012b). Recently, it has been shown that urea recycling contributes to nitrogen retention in milk-fed calves provided with a low-protein SF (Berends et al., 2012a) but this contribution decreases with increasing protein content in the SF (H. Berends, unpublished data).

Such interactions between MR and SF complicate an accurate prediction of the feeding value of a ration consisting of MR and SF in veal calves when based on well-documented separate effects of SF only (e.g., Ortigues et al., 1990) and MR only (e.g., Gerrits et al., 1996). Studying the effect of substantial exchanges of MR for SF raises methodological problems. The incremental feeding value of a particular mixture of SF is typically evaluated using a dose-response approach. When MR intake is fixed and an incremental dose of SF is provided (see e.g., Berends et al., 2012a), the assumption that differences in BW gain do not influence the feeding value of the SF provided may be violated. Furthermore, SF intake will likely affect the carcass weight:live weight ratio, which needs to be considered when comparing feeding strategies. When MR is exchanged for SF on a digestible energy (DE) basis (see e.g., Labussiere et al., 2009a), assumptions have to be made with regard to the DE content of all dietary ingredients before the start of the experiment. With increasing quantities of MR being replaced by $\mathrm{SF}$, these design problems are exacerbated. To circumvent these methodological issues, the current study assessed the feeding values of MR, concentrates, and roughages for veal calves in a paired-gain setup. Therefore, groups of calves were subjected to preset levels of concentrate and roughage intake, whereas the level of $\mathrm{MR}$ was adjusted to target equal rates of carcass gain across treatments. In this way, a substantial interchange of MR, concentrates, and roughages can be addressed while avoiding undesirable changes in the rate of BW gain. Differences in feeding values between these main ration components are addressed within the bounds of a particular choice of roughage and composition of concentrates or MR.

\section{MATERIALS AND METHODS}

This study was conducted at the research facilities of VanDrie Group (Scherpenzeel, the Netherlands). Procedures complied with the Dutch Law on Experimental Animals and the ETS123 (Council of Europe 1985 and the 86/609/EEC Directive) and were approved by the Animal Care and Use Committee of Wageningen University (Wageningen, the Netherlands).

\section{Animals, Experimental Design, and Housing}

One hundred sixty male Holstein-Friesian calves were purchased from commercial dairy farms at $2 \mathrm{wk}$ of age, selected based on BW, uniformity, and clinical health. Mean BW upon arrival was $45 \pm 0.2 \mathrm{~kg}$. Calves were randomly allocated to pens ( 5 calves per pen). We used a $2 \times 4$ factorial arrangement of treatments in a completely randomized experiment with 4 pens per treatment combination and pen as the experimental unit. We had 2 levels of roughage-to-concentrate (R:C) ratio, 20:80 or 50:50 on a DM basis, and 4 levels of SF: SF1, SF2, SF3, or SF4, respectively (Table 1). The experiment consisted of 2 successive periods - an adaptation period from wk 1 to 10 and an experimental period from wk 11 to 27 . During the adaptation period, all pens were exposed to their assigned SF level but an $\mathrm{R}$ :C ratio of 50:50 was used to allow for optimal rumen development as assessed in earlier studies (Berends et al., 2012b, Suárez et al., 2007). At the onset of the experimental period (i.e., at wk 11), pens were exposed to their assigned SF level and their assigned R:C ratio. Animal health was checked daily. Hemoglobin concentration in blood was monitored throughout the trial, at wk $3,7,11,15,19,23$, and at slaughter, and corrected to comply with the minimum EU level of $4.5 \mathrm{mmol} / \mathrm{L}$ at the end of the fattening period.

Pens measured $3 \times 3 \mathrm{~m}$ and were equipped with open fences and wooden-slatted floors, without bedding material. During the first $4 \mathrm{wk}$, calves were kept individually in $0.9-\mathrm{m}^{2}$ temporary pens placed inside the

Table 1. Experimental design and number of pens per treatment

\begin{tabular}{llcc}
\hline & & \multicolumn{2}{c}{${\text { No. of pens } / \text { treatment }^{2}}^{2}$} \\
\cline { 3 - 4 } Solid feed (SF) level & Target DMI & R:C 20:80 & R:C 50:50 \\
\hline SF1 & 20 & 4 & 4 \\
SF2 & 100 & 4 & 4 \\
SF3 & 180 & 4 & 4 \\
SF4 & 260 & 4 & 4 \\
\hline
\end{tabular}

${ }^{1}$ Cumulative DMI from solid feed (kg of DM) during the 17-wk experimental period.

${ }^{2} \mathrm{R}: \mathrm{C}=$ roughage-to-concentrate ratio on a DM basis. Roughage consisted of $50 \%$ corn silage and $50 \%$ chopped wheat straw on a DM basis. 
group pen to facilitate monitoring of individual feeding behavior and health. Calves were exposed to daylight and artificial light from 0500 to $2300 \mathrm{~h}$ and exposed to darkness during the remainder of the day.

\section{Diets and Feeding}

Roughage consisted of $50 \%$ corn silage and $50 \%$ chopped wheat straw on a DM basis (see Table 2 for composition). During the first $4 \mathrm{wk}$ of the adaptation period, corn silage was replaced, on a DM basis, with alfalfa hay to stimulate SF intake. The SF offered to calves increased at preplanned, equal weekly increments. Cumulative DMI from SF during the experimental period was targeted to reach $20 \mathrm{~kg}$ of $\mathrm{DM}$ for $\mathrm{SF} 1,100 \mathrm{~kg}$ of DM for SF2, $180 \mathrm{~kg}$ of DM for SF3, and $260 \mathrm{~kg}$ of DM for SF4. The quantity of MR was calculated to achieve similar targeted rates of carcass gain across treatments, and was adjusted every other week based on the realized BW gain in the preceding 2-wk period. Rates of carcass gain were estimated from the measured rates of BW gain. We assumed rumen tissue mass and contents to represent the most relevant difference between live weight gain and carcass weight gain (Berends et al., 2012b) and assumed these proportional to SF intake. Therefore, data from previous trials were used to predict rumen mass and content for each SF level (Suárez et al., 2007; Berends et al., 2012a).

Concentrate composition (Table 2) was designed to meet mineral and vitamin requirements for beef cattle (NRC, 2000). Milk replacer was reconstituted with water, and the concentration increased gradually from 125 to $188 \mathrm{~g} / \mathrm{L}$ for all treatments simultaneously during the experiment. The MR was supplied in buckets at 40 to $41^{\circ} \mathrm{C}$ and provided twice daily in equally sized meals at 0600 and $1600 \mathrm{~h}$. Calves were allowed $15 \mathrm{~min}$

Table 2. Analyzed nutrient composition ( $\mathrm{g} / \mathrm{kg}$ of DM) of concentrate, corn silage, and wheat straw fed during the 17-wk experimental period

\begin{tabular}{lccc}
\hline Nutrient & Concentrate $^{1}$ & $\begin{array}{c}\text { Corn } \\
\text { silage }\end{array}$ & $\begin{array}{c}\text { Wheat } \\
\text { straw }\end{array}$ \\
\hline DM, g/kg of product & 898 & 297 & 931 \\
CP $^{2}$ & 137 & 69 & 31 \\
Crude fat & 67 & 29 & 9 \\
Starch & 429 & 312 & 11 \\
NDF & 127 & 421 & 794 \\
\hline
\end{tabular}

${ }^{1}$ Concentrate composition: $36.2 \%$ corn, $20.6 \%$ lupins, $20.3 \%$ barley, $12.5 \%$ carob meal, $4.4 \%$ corn gluten meal, $6 \%$ premix (lactose carrier, provided per kilogram of concentrate: vitamin A: 4,000 IU; vitamin D: $500 \mathrm{IU}$; vitamin E: $100 \mathrm{IU}$; zinc $\left(\mathrm{ZnSO}_{4}\right): 25 \mathrm{mg}$; manganese $\left(\mathrm{MnSO}_{4}\right)$ : $20 \mathrm{mg}$; iodine (KI): $0.8 \mathrm{mg}$; iron $\left(\mathrm{FeSO}_{4}\right): 63 \mathrm{mg}$, selenium $\left(\mathrm{Na}_{2} \mathrm{SeO}_{3}\right)$ : $0.15 \mathrm{mg}$; copper $\left(\mathrm{CuSO}_{4}\right): 15 \mathrm{mg}$; cobalt: $0.1 \mathrm{mg} ; 1.13 \mathrm{~g}$ of magnesium (magnesium sulfate), $3.0 \mathrm{~g}$ of sodium $(\mathrm{NaCl}), 8.6 \mathrm{~g}$ of calcium $\left(\mathrm{CaCO}_{3}\right), 3.9 \mathrm{~g}$ of potassium $\left(\mathrm{KH}_{2} \mathrm{PO}_{4}\right)$.

${ }^{2} \mathrm{~N} \times 6.25$. to consume the milk; MR refusals were collected and weighed. During the first 8 wk of the adaptation period, calves received a commercial starter MR based on $32 \%$ whey powder and $30 \%$ skim milk powder with 223 $\mathrm{g}$ of $\mathrm{CP} / \mathrm{kg}$ of $\mathrm{DM}$ and $180 \mathrm{~g}$ of crude fat $/ \mathrm{kg}$ of DM. The experimental MR (Table 3) was provided during the last 2 wk of the adaptation period and during the experimental period and it was introduced over 3 feedings. The SF was provided as a TMR in a long feed trough in front of the pen, directly after the morning meal. Feed refusals were weighed once daily. During the first $4 \mathrm{wk}$ of the adaptation period, calves were allowed ad libitum access for 20 min to water supplied in buckets around noon. From wk 5 onward, calves had free access to water via drinking nipples.

\section{Measurements}

Feed Intake and Performance and Slaughter Procedure. Intake of MR and SF was recorded daily. Calves were weighed every 2 wk. At 27 wk, calves were transported for approximately $40 \min (45 \mathrm{~km})$ to a slaughter facility and killed by stunning (captive bolt pistol) and subsequent exsanguination. Measurement of carcass weight and classification of meat color and fat score were performed by a certified employee

Table 3. Ingredient composition and analyzed nutrient composition of the experimental milk replacer

Item

\begin{tabular}{lr}
\hline Ingredient, $\mathrm{g} / \mathrm{kg}$ & \\
Fat-filled whey powder $^{1}$ & 394.0 \\
Whey protein concentrate & 193.9 \\
Whey & 143.3 \\
Delactosed whey & 135.0 \\
Soy protein isolate & 37.7 \\
Soy protein concentrate & 25.0 \\
Acidified whey $^{2}$ & 20.0 \\
Pregelatinized wheat starch $^{3}$ & 20.0 \\
Vitamin and mineral premix $^{3}$ & 10.0 \\
Calcium formate & 9.8 \\
L-Lysine·HCl & 5.2 \\
DL-Methionine & 2.7 \\
Citric acid & 2.0 \\
Mono-ammonium phosphate & 1.4 \\
L-Threonine & 0.2 \\
Nutrient, g/kg of DM (unless otherwise stated) & 969.5 \\
DM, g/kg of product & 210.0 \\
CP & 211.6 \\
Crude fat & 22.3
\end{tabular}

${ }^{1}$ Contained 50\% fat from palm oil and coconut oil (80:20, wt/wt).

${ }^{2}$ Acidified with lactate, provided $5.9 \mathrm{~g}$ of lactate per kilogram of the experimental diet.

${ }^{3}$ Provided per kilogram of the experimental diet: $16.6 \mathrm{~g}$ of $\mathrm{K}, 15.5 \mathrm{~g}$ of $\mathrm{Cl}, 8.3 \mathrm{~g}$ of Fe, $6.1 \mathrm{~g}$ of P, $5.9 \mathrm{~g}$ of $\mathrm{Cu}\left(\mathrm{CuSO}_{4}\right), 5.7 \mathrm{~g}$ of Na, $1.3 \mathrm{~g}$ of $\mathrm{Mg}(\mathrm{MgO}), 25,000 \mathrm{IU}$ of vitamin $\mathrm{A}, 4,000 \mathrm{IU}$ of vitamin $\mathrm{D}_{3}, 100 \mathrm{IU}$ of vitamin $\mathrm{E}$.

${ }^{4}$ Calculated as $\mathrm{N} \times 6.25$. 
of the Central Office for Slaughter Livestock Services (BV CBS, Zeist, the Netherlands). Carcass gain was calculated by subtracting the estimated carcass weight at the start of the experimental period from the carcass weight. To estimate carcass weight at the start of the experimental period, dressing percentages obtained at the end of the experiment for the associated SF levels with R:C ratios of 50:50 were used. Meat color was scored on a 10-point scale from 1 (pale) to 10 (red) on the rectus abdominis muscle of the carcass using a handheld Konica-Minolta CR400 spectrophotometer (Konica-Minolta, Tokyo, Japan), as previously described by Hulsegge et al. (2001). Fat score of the carcasses was assessed by hypodermic fat coverage on the outside of the carcass and inside the chest cavity on a 5-point scale from 1 (no or very low amounts of fat) to 5 (carcass and chest cavity are covered with fat). The empty rumen weight was recorded. Rumen development was assessed by visual examination of the rumen mucosal surface and the presence and density of rumen papillae, and scored on a 5-point scale from 1 (minimal; few papillae or short papillae) to 5 (extensive; numerous, long and well-developed papillae), by an experienced pathologist-anatomist. Individual scores (i.e., fat, color, rumen development) were averaged per pen and subsequently treated as continuous variables. Abomasal damage was assessed by counting and scoring the size of lesions in the pyloric area of the abomasal wall, and was expressed as a product of counts and size. Lesions (erosions, ulcers, and scars) were categorized as small $\left(<0.5 \mathrm{~cm}^{2}\right)$, medium $(0.5$ to $\left.1.0 \mathrm{~cm}^{2}\right)$, or large $\left(>1.0 \mathrm{~cm}^{2}\right)$ and were assumed to be $0.25,0.75$, and $1.25 \mathrm{~cm}^{2}$, respectively.

Chemical Analyses. Samples of MR, concentrate, corn silage, and straw were collected weekly. Corn silage samples were pooled by month; other samples were pooled for the experimental period. All samples were analyzed for DM, CP, starch, NDF (except for MR), and crude fat contents. For determination of DM content, corn silage and concentrate samples were freezedried. Concentrate, straw, and corn silage samples were ground to pass a 1-mm screen. Dry matter content was determined by drying to a constant weight according to ISO standard 6496 (ISO, 1998). Kjeldahl N content was determined according to ISO standard 5983 (ISO, 1997). Crude fat content was determined following acid hydrolysis according to ISO standard 6496 (ISO, 1999). The NDF content was analyzed according to Van Soest et al. (1991). Starch content was determined enzymatically as described by Rijnen et al. (2001). Before starch analysis, reducing sugars were extracted from the samples according to the Luff-Schoorl method (NEN, 1974), using $40 \%$ ethanol and subsequent hydrolysis in a weak acid environment.

\section{Statistical Analysis}

In total, 15 calves were excluded from the experiment: 6 calves during the adaptation period and 9 calves during the experimental period due to clinical sickness ( $\mathrm{n}$ $=7$; e.g., lung infection, diarrhea $)$ or death $(\mathrm{n}=2)$. Pen was considered the experimental unit, and dependent variables were averaged per pen before statistical evaluation. Dependent variables were analyzed using analysis of covariance (SAS version 9.2; SAS Institute Inc., Cary, NC). The model comprised SF intake as a covariate and the interaction between $\mathrm{SF}$ intake and $\mathrm{R}$ :C ratio to estimate regression coefficients for both $\mathrm{R}: \mathrm{C}$ ratios. The main effect of $\mathrm{R}: \mathrm{C}$ ratio was excluded to obtain a single intercept, which represents the value of the dependent variable when SF intake is zero (i.e., $\mathrm{R}$ :C ratio of $\mathrm{SF}$ is meaningless). The number of calves in a pen $(3,4$, or 5$)$ was included in a weight statement to account for differences in reliability of pen means. Residual carcass gain was included as a covariate in the model to account for within-treatment variation of carcass gain when the dependent variable was DMI from MR, fat score, color score, or live weight gain. Residual carcass gain was calculated for each pen by difference between the pen mean and the treatment mean. When model residuals were not normally distributed, data were transformed to obtain homogeneity of variance. Data are presented as raw means with standard errors of the means, and $P$-values were obtained from analysis of the normally distributed data (after transformation if required). Regression coefficients are presented with their common intercept.

To evaluate time-related changes in MR intake to achieve similar rates of carcass gain, biweekly (every other week) data were analyzed. Biweekly rates of MR intake, expressed as MR intake per kilogram of carcass gain ( $\mathrm{kg} \mathrm{DM}$ of $\mathrm{MR} / \mathrm{kg}$ of carcass gain), was considered the dependent variable. Fixed effects of SF intake $(\mathrm{kg}$ of $\mathrm{DM} / \mathrm{d}$ ) as co-variable, and the interaction between $\mathrm{SF}$ intake and $\mathrm{R}: \mathrm{C}$ ratio on the dependent variable were analyzed for every 2 -wk period. The significance of the decline in regression coefficients was determined by analysis of covariance (SAS Institute Inc.) with time (i.e., 2-wk period) as a covariate, including the interaction between R:C ratio and time. Differences were considered significant at $P<0.05$.

\section{RESULTS}

Realized cumulative DMI from SF were very close to targeted DMI (Table 4). Figure 1 shows the effect of $\mathrm{R}: \mathrm{C}$ ratio on the relationship between total DMI from MR and total DMI from SF over the 17-wk experimental period. The regression coefficients in Figure 1 repre- 
sent the change in MR intake (in $\mathrm{kg}$ of $\mathrm{DM}$ ) to achieve similar rates of carcass gain per 1-kg increase in DMI from $\mathrm{SF}$ for each $\mathrm{R}$ :C ratio. The regression coefficient for the R:C ratio of 50:50 was $-0.41 \mathrm{~kg}$ of $\mathrm{MR} / \mathrm{kg}$ of $\mathrm{SF}$ and differed $(P<0.001)$ from the regression coefficient for the $\mathrm{R}: \mathrm{C}$ ratio of $20: 80$, which was $-0.53 \mathrm{~kg}$ of MR/ $\mathrm{kg}$ of SF. Carcass gain during the experimental period, however, increased slightly with $\mathrm{SF}$ intake $(P<0.01$; Table 5), independent of the $\mathrm{R}: \mathrm{C}$ ratio. Due to unexpected high rates of $\mathrm{BW}$ gain of calves at the high SF intakes, the paired-gain objective was not completely achieved. The MR allowance required to achieve the same BW gain for calves at the low SF intakes was beyond the intake capacity of these calves. To correct for differences in carcass gain, the effect of $\mathrm{R}$ : $\mathrm{C}$ ratio on MR intake per kilogram of carcass gain was analyzed. The regression coefficients were -0.0077 and -0.0086 $\mathrm{kg}$ of $\mathrm{MR} / \mathrm{kg}$ of carcass gain and per $\mathrm{kg}$ of $\mathrm{SF}$ for R:C ratios of 50:50 and 20:80, respectively (Table 5) and differed $(P<0.05)$ from each other.

The effect of time on the relationship between MR intake, expressed per kilogram of carcass gain, and SF intake is shown in Figure 2. These biweekly regression coefficients were obtained from 2 -wk averages of SF intake (Supplemental Figure S1; http://dx.doi. org/10.3168/jds.2014-8098), MR intake (Supplemental Figure S2), and carcass gain (Supplemental Figure S3). The regression coefficients, representing the reduction in MR intake per $\mathrm{kg}$ of $\mathrm{SF}$ per $\mathrm{kg}$ of carcass gain for a 2 -wk period, decreased with time $(P<0.05)$. The decrease with time was greater for the $\mathrm{R}$ : $\mathrm{C}$ ratio of 20:80 than for 50:50 $(P<0.01)$.

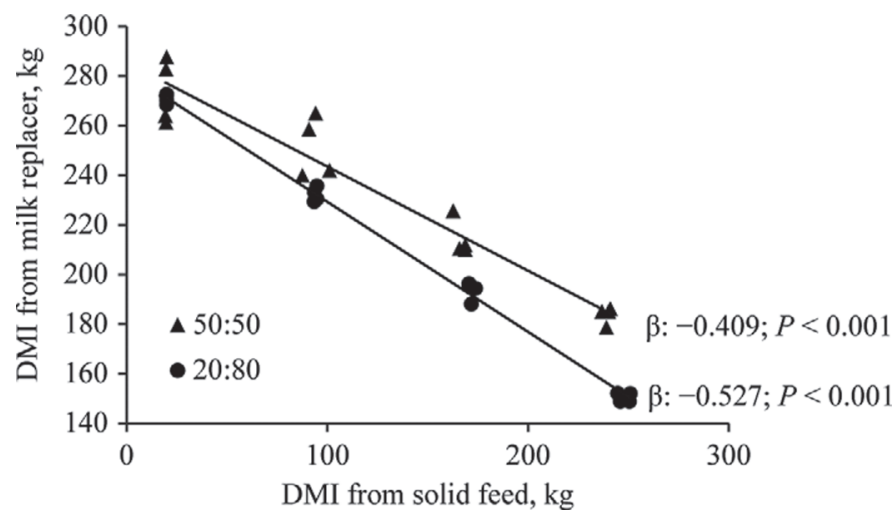

Figure 1. Relationship between total DMI from solid feed and DMI from milk replacer at 2 roughage-to-concentrate ratios ( $\mathbf{\Lambda}: 50: 50$, -: 20:80) in veal calves in a paired-gain design from wk 11 to 27 of the experiment. Each observation includes a pen of 3 to 5 animals. Roughage consisted of 50\% corn silage and $50 \%$ chopped wheat straw based on DM. The regression coefficient $(\beta)$ represents the change in milk replacer intake required to maintain growth rate when increasing solid feed intake ( $\mathrm{kg}$ of $\mathrm{DM} / \mathrm{kg}$ of DM). Regression coefficients differed $(P<0.01)$ between roughage-to-concentrate ratios (see also Table 5$)$.

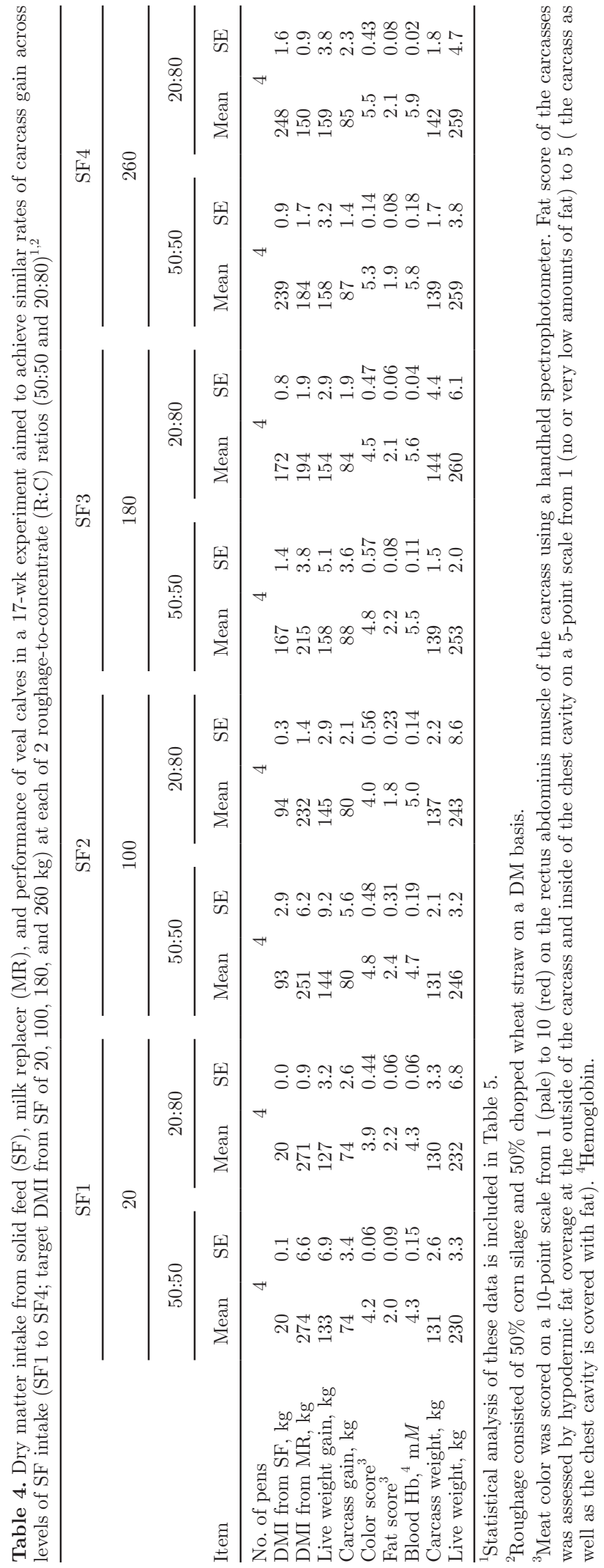

Journal of Dairy Science Vol. 97 No. 10, 2014 
Table 5. Effects of incremental DMI from solid feed (SF) on selected response parameters in veal calves at 2 roughage-to-concentrate (R:C) ratios (50:50 and 20:80); the 17-wk experiment aimed to achieve similar rates of carcass gain across levels of SF intake

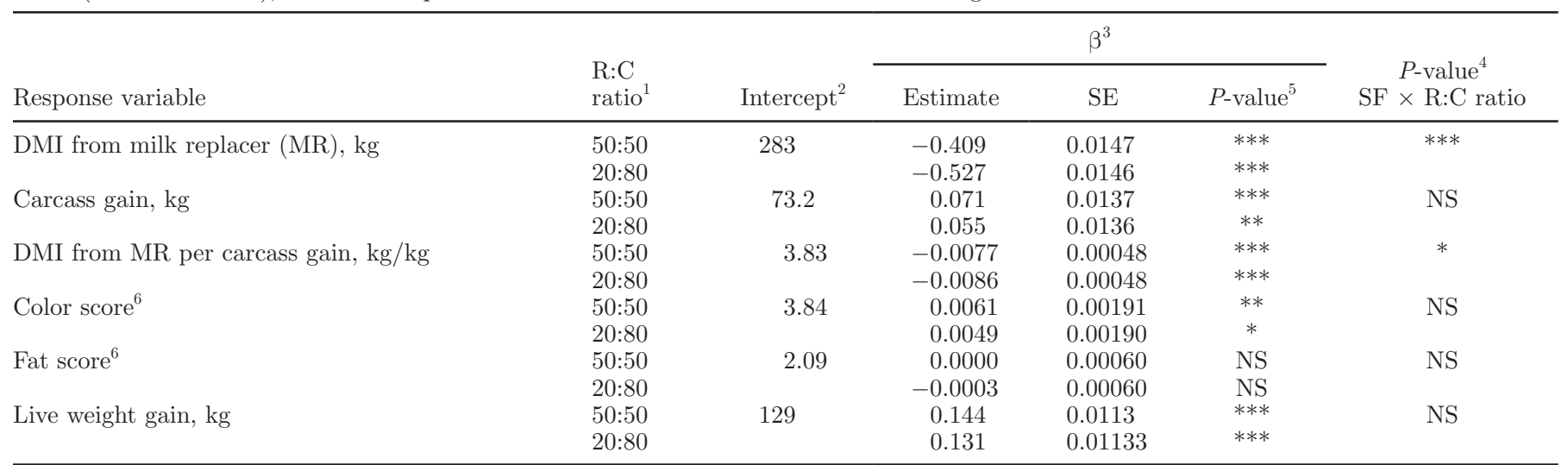

${ }^{1}$ Roughage consisted of $50 \%$ corn silage and $50 \%$ chopped wheat straw on a DM basis.

${ }^{2}$ Estimate of the response variable for calves without SF.

${ }^{3}$ Regression coefficient $\beta(y=a+\beta \cdot x)$ represents the change in response variable per increase in DMI from SF.

${ }^{4} \mathrm{~A}$ significant interaction between the DMI from SF and the R:C ratio indicates that the regression coefficient differs between the R:C ratios. The effect of residual carcass gain (observed carcass gain - average carcass gain per treatment) was included for DMI from MR, color score, fat score and live weight gain, and found significant for DMI from MR, fat score, and for live weight gain.

${ }^{5}$ Probability for test whether the regression coefficient $(\beta)$ equals 0 .

${ }^{6}$ Meat color was scored on a 10-point scale from 1 (pale) to 10 (red) on the rectus abdominis muscle of the carcass using a handheld spectrophotometer. Fat score of the carcasses was assessed by hypodermic fat coverage at the outside of the carcass and inside of the chest cavity on a 5-point scale from 1 (no or very low amounts of fat) to 5 (the carcass as well as the chest cavity is covered with fat). Data were transformed (arsin, sqrt) to obtain homogeneity of variance.

$\dagger P<0.10 ; * P<0.05 ;{ }^{*} * P<0.01 ; * * * P<0.001$.

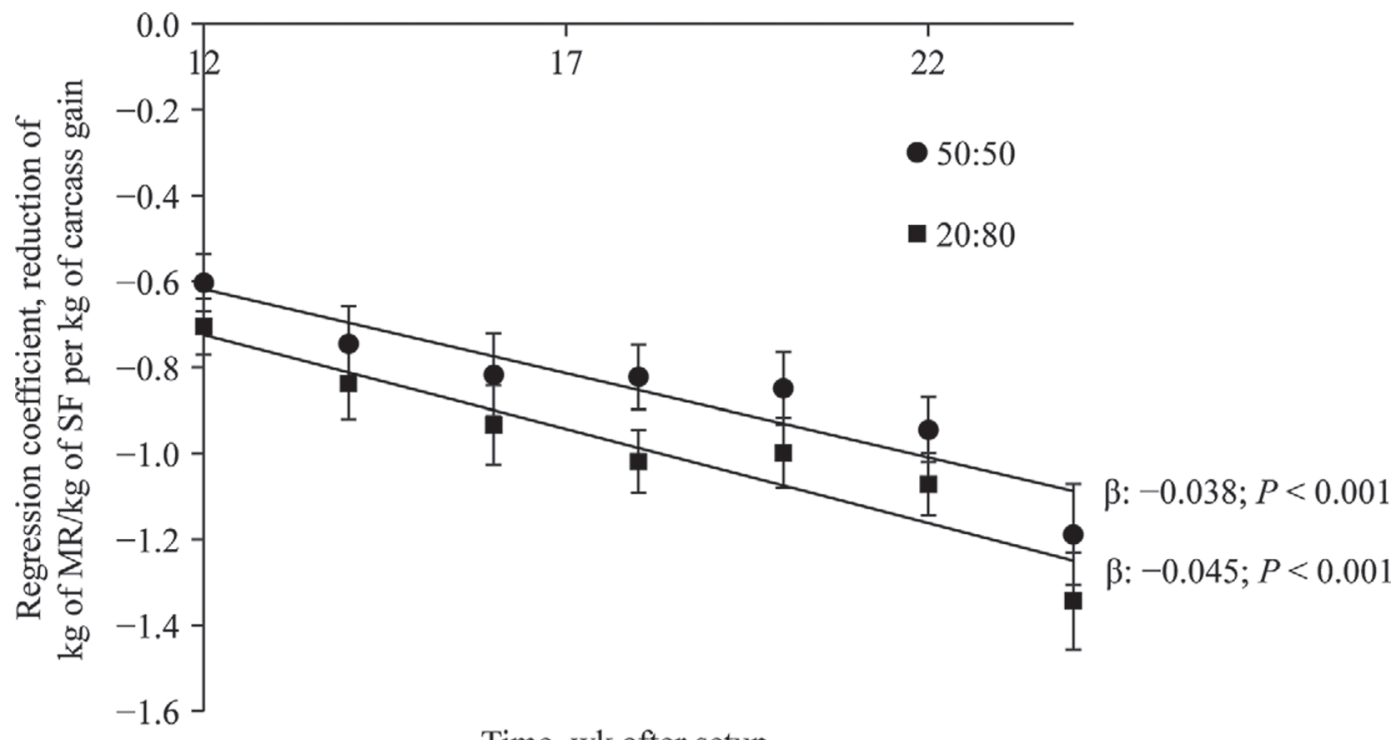

Time, wk after setup

Figure 2. Linear regression between the regression coefficients describing the relationship between milk replacer $(\mathrm{MR}$, $\mathrm{kg}$ of $\mathrm{DM} / \mathrm{d})$ intake,

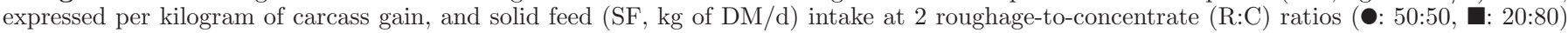
from wk 11 to 27 after set-up in veal calves in a paired-gain design. Each observation represents the regression coefficient at a given time point, based on a 2-wk period, after set-up at 2 wk of age. For both R:C ratios, regression coefficients decreased with time $(P<0.001)$ and this decline was smaller $(P<0.01)$ for an R:C ratio of 50:50 than for 20:80. Roughage consisted of 50\% corn silage and 50\% chopped wheat straw based on DM. 
Table 6. Effects of incremental DMI from solid feed (SF) on postmortem variables at 2 roughage-to-concentrate (R:C) ratios (50:50 and 20:80) in veal calves in a paired-gain set-up

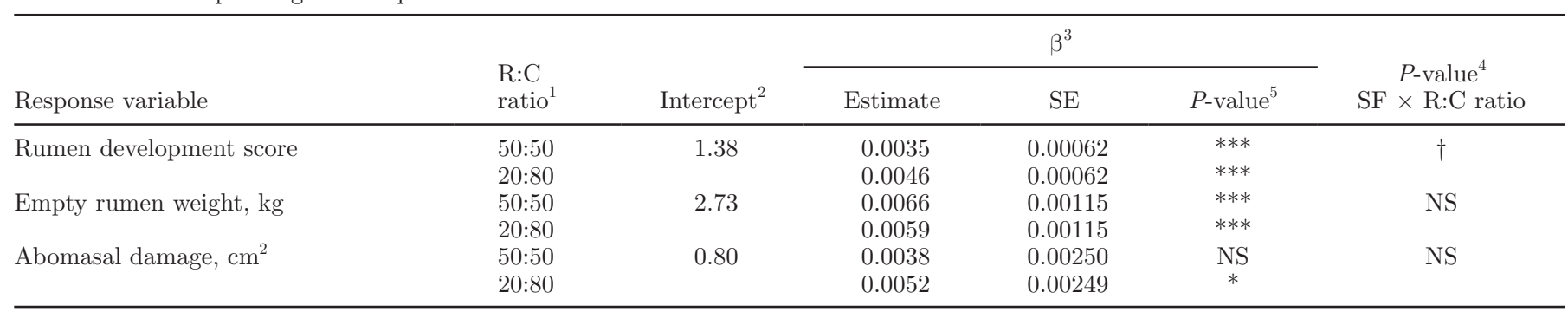

${ }^{1}$ Roughage consisted of $50 \%$ corn silage and $50 \%$ chopped wheat straw on a DM basis.

${ }^{2}$ Estimate of the response parameter for calves without solid feed.

${ }^{3}$ Regression coefficient $\beta(y=a+\beta \cdot x)$ represents the change in response variable per increase in DMI from solid feed.

${ }^{4} \mathrm{~A}$ significant interaction between the DMI from SF and the R:C ratio indicates that the regression coefficient differs between the R:C ratios. The effect of residual carcass gain was not significant for any response parameter.

${ }^{5}$ Probability for test if the regression coefficient $(\beta)$ equals 0.

$\dagger P<0.10 ;{ }^{*} P<0.05 ;{ }^{* * *} P<0.001$.

Carcass color score tended to increase with SF intake $(P<0.10$; Table 5$)$. Fat score of the carcass was unaffected by $\mathrm{SF}$ intake and $\mathrm{R}: \mathrm{C}$ ratio. Live weight gain increased with SF intake $(P<0.001)$ and this increase did not differ between R:C ratios. Rumen development score increased with SF intake $(P<0.001)$, and this increase tended to be greater for the $\mathrm{R}: \mathrm{C}$ ratio of $20: 80$ (Table 6). Empty rumen weight increased $(P<0.001)$ with SF intake and ranged between 2.24 and $5.18 \mathrm{~kg}$. The surface area of abomasal damage ranged from 0.1 to $4.3 \mathrm{~cm}^{2}$ and increased with $\mathrm{SF}$ intake for $\mathrm{R}$ :C ratio 20:80 $(P<0.05)$, but not for 50:50, although the interaction was not significant $(P=0.11)$.

\section{DISCUSSION}

\section{Utilization of SF for Growth and Effect of R:C Ratio}

We aimed to investigate the feeding values of MR, roughage, and concentrates for veal calves in a pairedgain setting, thus avoiding any prior assumptions in feeding values and large differences in nutrient intakes. The feeding value of SF is expressed as the reduction in MR intake ( $\mathrm{kg}$ of DM) to realize equal rates of carcass gain with increasing SF intake ( $\mathrm{kg}$ of $\mathrm{DM})$, and can be derived by regression of MR intake and SF intake (Figure 1). For an R:C ratio of 50:50, MR intake decreased by $409 \mathrm{~g}$ of DM for each extra kilogram of DM SF; for an $\mathrm{R}: \mathrm{C}$ ratio of 20:80, this was $529 \mathrm{~g} \mathrm{DM}$ of MR. Thus, the amount of MR required to realize equal rates of carcass gain was almost $25 \%$ lower for an $\mathrm{R}$ : $\mathrm{C}$ ratio of 20:80 than 50:50, indicating that utilization of SF for growth is increased with the proportion of concentrate in the SF. After correction for the observed increase in carcass gain with SF intake $(6.3 \mathrm{~kg}$ per $100 \mathrm{~kg}$ DM of
SF; $P<0.001$; Table 5), the average reduction of MR intake to realize equal rates of carcass gain was still lower for the R:C ratio of $50: 50(0.63 \mathrm{~kg}$ of $\mathrm{MR} / \mathrm{kg}$ of $\mathrm{SF})$ than for the R:C ratio of 20:80 (0.70 kg of MR/kg of SF).

Differences in digestibility of energy from concentrates, roughages, and MR contribute, to a large extent, to variation in their feeding value. When assuming additivity of MR and SF, it would not make a difference whether DE originates from MR or SF. Based on this assumption, we calculated the decrease in $\mathrm{DE}$ from MR with increasing DE from SF at each of the $2 \mathrm{R}$ :C ratios. The estimated DE content of MR was $18.5 \mathrm{MJ} /$ $\mathrm{kg}$ of DM, as calculated from the analyzed gross energy value and a digestibility of gross energy of $96 \%$ (van den Borne et al., 2006b; Labussiere et al., 2009b). The estimated DE content of SF was $10.8 \mathrm{MJ} / \mathrm{kg}$ of DM for an $\mathrm{R}: \mathrm{C}$ ratio of 50:50 (Berends et al., 2012a) and 13.1 $\mathrm{MJ} / \mathrm{kg}$ of DM for an R:C ratio of 20:80 (J. J. G. C. van den Borne, unpublished data). These digestibility studies in veal calves (Berends et al., 2012a; J. J. G. C. van den Borne, unpublished data) used identical R:C ratios and roughage and concentrate sources as in the current study. Based on these estimates, the reduction of MR intake with increasing SF intake would then be 0.58 and $0.71 \mathrm{~kg}$ of $\mathrm{MR} / \mathrm{kg}$ of $\mathrm{SF}$ for $50: 50$ and 20:80, respectively. These calculated values are only slightly different from the average values obtained in the current study $(0.62$ and $0.69 \mathrm{~kg}$ of MR/ $\mathrm{kg}$ of SF for 50:50 and 20:80, respectively). Differences between SF and MR in postabsorptive utilization of DE could be affected by energy used by visceral tissues (Reynolds et al., 1991a,b), and methane losses with SF intake in veal calves (Berends et al., 2012a). The reduction in MR intake to realize equal rates of carcass gain with 
increasing SF intake is close to those calculated based on DE, assuming additivity of feeding values of MR, roughages, and concentrates.

If digestible CP (DCP) were the main driving force for carcass gain, it would not matter whether the DCP originated from MR or SF. Therefore, we calculated the decrease in DCP from MR required for equal carcass gain with increasing DCP for SF at each of the 2 $\mathrm{R}: \mathrm{C}$ ratios. When assuming DCP contents of MR, SF 50:50, and SF 20:80 at 197, 42, and $66 \mathrm{~g} / \mathrm{kg}$ based on calf studies (Ortigues et al., 1990; Moody et al., 2007; Labussiere et al., 2009a), the reduction in MR intake with increasing SF intake would be $0.21 \mathrm{~kg}$ of $\mathrm{MR} / \mathrm{kg}$ of $\mathrm{SF}$ for an R:C ratio of 50:50 and $0.33 \mathrm{~kg}$ of $\mathrm{MR} / \mathrm{kg}$ of $\mathrm{SF}$ for an R:C ratio of 20:80. Hence, the theoretical reduction in $\mathrm{MR}$ intake with increasing $\mathrm{SF}$ intake is only 34 to $48 \%$ of the reduction observed in the current study, suggesting that DE from SF was more limiting than DCP when exchanging MR for SF. In dairy calves, it was shown that at weaning, increasing ME intake resulted in increased weight gain, whereas increasing protein supply had no effect (Journet, 1984). Potential effects of urea recycling were excluded from this calculation. Nitrogen from MR may be reutilized for protein gain due to urea recycling when providing SF (Berends et al., 2014), but the quantitative contribution of urea recycling to protein gain depends on the $\mathrm{N}$ level of $\mathrm{SF}$ (H. Berends, unpublished data).

Thus, the average reduction in MR intake with increasing SF intake realized throughout the experimental period is in close accordance with the theoretical predictions by exchanging SF for MR based on DE supply. These data indicate that the feeding value of solid feeds for calf diets can be estimated from DE content.

However, this average reduction realized throughout the experimental period does not account for the large variation observed in time. The regression coefficients, representing the reduction in MR intake with increasing SF intake ( $\mathrm{kg}$ of $\mathrm{MR} / \mathrm{kg}$ of $\mathrm{SF}$ per $\mathrm{kg}$ of carcass gain per day) decreased during the experiment for both $\mathrm{R}: \mathrm{C}$ ratios (Figure 2), indicating that the utilization of $\mathrm{SF}$ for growth relative to MR increased with age. Although the regression coefficients decrease with age, a linear fit may not be optimal. The pattern of decline in time, which was similar for both R:C ratios, may need further study of the potential underlying mechanisms. The decline was greater for an R:C ratio of 20:80 than for 50:50 $(P<0.01)$, which may be explained by the inclusion of concentrate or a reduced efficiency of MR utilization or both. Utilization of protein from MR for growth is known to decrease with increasing age in milk-fed calves (Gerrits et al., 1996; van den Borne et al., 2006a), whereas the utilization of SF increased with age in veal calves between 108 to $164 \mathrm{~kg}$ of BW (Berends et al., 2012a). As in dairy calves (Hodgson, 1971), SF intake may increase rumen volume, resulting in greater rumen retention time and degradation. Furthermore, rumen functioning and fermentation were shown to improve with age in calves fed exclusively SF (Devant et al., 2000; Rotger et al., 2005). The latter corresponds with previous observations in veal calves, where early initiation of rumen development was suggested to result in increased nutrient utilization, especially during the second half of the fattening period (Berends et al., 2012b). Additionally, leakage of MR into the rumen, referred to as ruminal drinking, may increase with age (Guilhermet et al., 1975). Increased ruminal drinking could reduce utilization of MR for gain and thus a relatively greater utilization of SF when exchanging SF for MR to obtain equal growth rates. In addition, ruminal drinking may interfere with microbial fermentation processes in the rumen and could thus affect utilization of SF. Finally, urea recycling in milkfed calves provided with SF increased with increasing age (Berends et al., 2012a), which has been associated with increased utilization of $\mathrm{N}$ from MR (H. Berends, unpublished data).

\section{Rumen Development and Abomasal Damage}

An increased supply of end products from rumen fermentation, due to either increased SF intake or concentrate inclusion, can be expected to increase papillae development (Tamate et al., 1962). Rumen development score and empty rumen weight both increased with increasing SF intake, which is in agreement with previous studies in veal calves (Morisse et al., 2000; Berends et al., 2012b). Empty rumen weights were in the upper range of or above previously reported values in veal calves of similar age, which may be explained by the lower level of SF intake $(<750 \mathrm{~g}$ of DM/d) than in the current study $(<3,000 \mathrm{~g}$ of DM/d) (Morisse et al., 2000; Berends et al., 2012b). Inclusion of 30 to $60 \%$ roughage (from various sources) at the expense of concentrates decreased empty rumen weight in veal calves at $10 \mathrm{wk}$ of age (Suárez et al., 2007). In the current study, the increase in rumen development score tended to be $(P<0.10)$ greater for an R:C ratio of 20:80 than for a ratio of 50:50, which may be explained by greater concentrations of VFA in the rumen with increasing concentrate supply (Berends et al., 2012b). The surface of abomasal damage increased with SF intake for an R:C ratio of 20:80 $(P<0.05)$, but not for 50:50 (interaction $\mathrm{SF}$ intake $\times \mathrm{R}: \mathrm{C}$ ratio: $P=0.11$ ). Other studies showed that provision of SF to milk-fed calves increased the prevalence of abomasal damage, 
including pyloric ulcers, when compared with calves fed MR only (Breukink et al., 1991; Mattiello et al., 2002; Brscic et al., 2011). Solid feed particles may exert mechanically abrasive effects on the abomasal mucosa, which may be sensitized due to provision of large volumes of MR. Promoting early rumen development was previously hypothesized to stimulate fermentative degradation of particles; thereby reducing abomasal damage in veal calves (Berends et al., 2012b). In that study, early rumen development reduced the prevalence of large scars in the abomasum compared with late rumen development (6 vs. $20 \%$ of calves; Berends et al., 2012b). The current study used a larger contrast in SF intake but did not include roughage proportions over $50 \%$.

\section{CONCLUSIONS}

The aim of the current study was to investigate feeding values of MR, roughage, and concentrates for the formulation of veal calf diets with substantial amounts of SF. The quantity of MR fed to realize equal rates of carcass gain was 10\% lower for the 20:80 than for the 50:50 R:C ratio, indicating that utilization of SF for gain increased with concentrate inclusion. Averaged over the 16-wk experimental period, the feeding value of MR relative to that of concentrates and roughages was close to that predicted based on their respective DE contents. Nevertheless, the feeding value of SF relative to that of MR increased substantially with age. Therefore, additivity in feeding values of these ration components cannot be assumed. The surface of abomasal damage increased with SF intake for an R:C ratio of 20:80, but not for 50:50. Rumen development score increased with SF intake.

\section{ACKNOWLEDGMENTS}

The authors thank the Division for Earth and Life Sciences (ALW) of the Netherlands Organisation for Scientific Research (NWO, The Hague, the Netherlands), and the Product Board Animal Feed (The Hague, the Netherlands) for financially supporting this research. We thank Klaas Boeder, Bart Evers, Ewart van Voorst (all of the VanDrie Group, Scherpenzeel, the Netherlands), Bert Beukers, André Jansen, Joswita van der Velde (all of Wageningen University, Wageningen, the Netherlands), Norbert Stockhofe-Zurwieden, Ralph Kok, Pieter Roskam (all of Central Veterinary Institute, Lelystad, the Netherlands), and Bas Engel (Biometris, Wageningen, the Netherlands) for their contributions.

\section{REFERENCES}

Berends, H., J. J. G. C. van den Borne, S. J. J. Alferink, C. G. van Reenen, E. A. M. Bokkers, and W. J. J. Gerrits. 2012a. Low-protein solid feed improves the utilization of milk replacer for protein gain in veal calves. J. Dairy Sci. 95:6654-6664.

Berends, H., J. J. G. C. van den Borne, B. A. Røjen, J. van Baal, and W. J. J. Gerrits. 2014. Urea recycling contributes to nitrogen retention in calves fed milk replacer and low-protein solid feed. J. Nutr. 144:1043-1049. http://dx.doi.org/10.3945/jn.114.191353.

Berends, H., C. G. van Reenen, N. Stockhofe-Zurwieden, and W. J. J. Gerrits. 2012b. Effects of early rumen development and solid feed composition on growth performance and abomasal health in veal calves. J. Dairy Sci. 95:3190-3199.

Breukink, H. J., T. Wensing, and J. M. Mouwen. 1991. Abomasal ulcers in veal calves: Pathogenesis and prevention. Pages 118-122 in Proc. Int. Symp. Veal Calf Production. Pudoc Wageningen, Wageningen, the Netherlands.

Brscic, M., L. F. M. Heutinck, M. Wolthuis-Fillerup, N. Stockhofe, B. Engel, E. K. Visser, F. Gottardo, E. A. M. Bokkers, B. J. Lensink, G. Cozzi, and C. G. Van Reenen. 2011. Prevalence of gastrointestinal disorders recorded at postmortem inspection in white veal calves and associated risk factors. J. Dairy Sci. 94:853-863.

Devant, M., A. Ferret, J. Gasa, S. Calsamiglia, and R. Casals. 2000 Effects of protein concentration and degradability on performance, ruminal fermentation, and nitrogen metabolism in rapidly growing heifers fed high-concentrate diets from 100 to $230 \mathrm{~kg}$ body weight. J. Anim. Sci. 78:1667-1676.

Gerrits, W. J. J., G. H. Tolman, J. W. Schrama, S. Tamminga, M. W. Bosch, and M. W. A. Verstegen. 1996. Effect of protein and protein-free energy intake on protein and fat deposition rates in preruminant calves of 80 to $240 \mathrm{~kg}$ live weight. J. Anim. Sci. 74:2129-2139.

Guilhermet, R., C. Mathieu, and R. Toullec. 1975. Transit des aliments liquides au niveau de la gouttiere oesophagienne chez le veau preruminant et ruminant. Ann. Zootech. 24:69-79.

Hodgson, J. 1971. The development of solid food intake in calves 3. The relation between solid food intake and the development of the alimentary tract. Anim. Sci. 13:449-460.

Hulsegge, B., B. Engel, W. Buist, G. Merkus, and R. Klont. 2001. Instrumental colour classification of veal carcasses. Meat Sci. $57: 191-195$.

ISO (International Organization for Standardization). 1997. Animal feeding stuffs - Determination of nitrogen content and calculation of crude protein content. ISO 5983. ISO, Geneva, Switzerland.

ISO (International Organization for Standardization). 1998. Animal feeding stuffs - Determination of moisture and other volatile matter content. ISO 6496. ISO, Geneva, Switzerland.

ISO (International Organization for Standardization). 1999. Animal feeding stuffs - Determination of fat content. ISO 6492. ISO, Geneva, Switzerland.

Journet, M. 1984. Nutrition des veaux au cours du sevrage. I. Evolution de la consommation d'aliments et des concentrations sanguines de divers métabolites énergétiques. Ann. Zootech. 33:427-444.

Kooijman, J., H. K. Wierenga, and P. R. Wiepkema. 1991. Development of abnormal oral behaviour in group-housed veal calves: Effects of roughage supply. Pages 54-60 in New Trends in Veal Calf Production; Proc. Int. Symp. Veal Calf Production. J. H. M. Metz and C. M. Groenestein, ed. EAAP Publications, Pudoc, Wageningen, the Netherlands.

Labussiere, E., S. Dubois, J. van Milgen, G. Bertrand, and J. Noblet. 2009a. Effect of solid feed on energy and protein utilization in milk-fed veal calves. J. Anim. Sci. 87:1106-1119.

Labussiere, E., G. Maxin, S. Dubois, J. van Milgen, G. Bertrand, and J. Noblet. 2009b. Effect of feed intake on heat production and protein and fat deposition in milk-fed veal calves. Animal 3:557-567.

Mattiello, S., E. Canali, V. Ferrante, M. Caniatti, F. Gottardo, G. Cozzi, I. Andrighetto, and M. Verga. 2002. The provision of solid feeds to veal calves: II. Behavior, physiology, and abomasal damage. J. Anim. Sci. 80:367-375. 
Moody, M. L., G. Zanton, J. Daubert, and A. Heinrichs. 2007. Nutrient utilization of differing forage-to-concentrate ratios by growing Holstein heifers. J. Dairy Sci. 90:5580-5586.

Morisse, J. P., D. Huonnic, J. P. Cotte, and A. Martrenchar. 2000. The effect of four fibrous feed supplementations on different welfare traits in veal calves. Anim. Feed Sci. Technol. 84:129-136.

NEN. 1974. Onderzoekingsmethoden voor veevoeders - Bepaling van het gehalte aan reducerende suiker, ruwe totaal suiker, saccharose en ruwe lactose. NEN (Nederlandse Norm), Delft, the Netherlands.

NRC. 2000. Nutrient Requirements of Beef Cattle. 7th rev. ed. Natl. Acad. Press, Washington, DC.

Ortigues, I., T. Smith, M. Gill, S. B. Cammell, and N. W. Yarrow. 1990. The effect of fishmeal supplementation of a straw-based diet on growth and calorimetric efficiency of growth in heifers. Br. J. Nutr. 64:639-651.

Reynolds, C. K., H. F. Tyrrell, and P. J. Reynolds. 1991a. Effects of diet forage-to-concentrate ratio and intake on energy metabolism in growing beef heifers: Net nutrient metabolism by visceral tissues. J. Nutr. 121:1004-1015.

Reynolds, C. K., H. F. Tyrrell, and P. J. Reynolds. 1991b. Effects of diet forage-to-concentrate ratio and intake on energy metabolism in growing beef heifers: whole body energy and nitrogen balance and visceral heat production. J. Nutr. 121:994-1003.

Rijnen, M. M., M. Verstegen, M. Heetkamp, J. Haaksma, and J. Schrama. 2001. Effects of dietary fermentable carbohydrates on energy metabolism in group-housed sows. J. Anim. Sci. 79:148-154.

Rotger, A., A. Ferret, S. Calsamiglia, and X. Manteca. 2005. Changes in ruminal fermentation and protein degradation in growing Holstein heifers from 80 to $250 \mathrm{~kg}$ fed high-concentrate diets with different forage-to-concentrate ratios. J. Anim. Sci. 83:1616-1624.

Suárez, B. J., C. G. Van Reenen, W. Gerrits, N. Stockhofe, A. Van Vuuren, and J. Dijkstra. 2006. Effects of supplementing concen- trates differing in carbohydrate composition in veal calf diets: II Rumen development. J. Dairy Sci. 89:4376-4386.

Suárez, B. J., C. G. Van Reenen, N. Stockhofe, J. Dijkstra, and W. J. J. Gerrits. 2007. Effect of roughage source and roughage to concentrate ratio on animal performance and rumen development in veal calves. J. Dairy Sci. 90:2390-2403.

Tamate, H., A. D. McGilliard, N. L. Jacobson, and R. Getty. 1962 Effect of various dietaries on the anatomical development of the stomach in the calf. J. Dairy Sci. 45:408-420.

van den Borne, J. J., J. Verdonk, J. W. Schrama, and W. J. J. Gerrits. 2006a. Reviewing the low efficiency of protein utilization in heavy preruminant calves - A reductionist approach. Reprod. Nutr. Dev. 46:121-137.

van den Borne, J. J., M. W. A. Verstegen, S. J. J. Alferink, R. M. M. Giebels, and W. J. J. Gerrits. 2006b. Effects of feeding frequency and feeding level on nutrient utilization in heavy preruminant calves. J. Dairy Sci. 89:3578-3586.

Van Soest, P. J., J. Robertson, and B. Lewis. 1991. Methods for dietary fiber, neutral detergent fiber, and nonstarch polysaccharides in relation to animal nutrition. J. Dairy Sci. 74:3583-3597.

Veissier, I., A. R. Ramirez De La Fe, and P. Pradel. 1998. Nonnutritive oral activities and stress responses of veal calves in relation to feeding and housing conditions. Appl. Anim. Behav. Sci. 57:35-49.

Webb, L. E., E. A. Bokkers, B. Engel, W. J. Gerrits, H. Berends, and C. G. van Reenen. 2012. Behaviour and welfare of veal calves fed different amounts of solid feed supplemented to a milk replacer ration adjusted for similar growth. Appl. Anim. Behav. Sci. 136:108-116

Welchman, D. D., and G. N. Baust. 1987. A survey of abomasal ulceration in veal calves. Vet. Rec. 121:586-590. 